\title{
DYNAMIC STABILITY CRITERION FOR THE EVALUATION OF A STEEL INDUSTRIAL HALL WITH INTERNAL TRANSPORT
}

\begin{abstract}
The paper presents the problem of dynamic criterion of stability loss of industrial hall with internal transport. The analysis was performed with finite element method. As a result of the calculation the relationship of eigenfrequency and axial compressive force was presented. On the basis of these results fundamental recommendations formulated for designers of steel halls with internal transport.
\end{abstract}

Keywords: steel halls, internal transport, stability, dynamics

\section{Introduction}

Steel halls are widespread in today's industrial construction. Versatile qualities of steel provide structural engineers and architects with a wide range of opportunities to design a variety of structures from simple portal frames to state of the art projects with non-conventional shapes and functions. The structures are constructed relatively quickly and their price is more attractive than that of masonry buildings. Steel halls can be easily extended and adapted according to the needs of clients [1].

The majority of steel halls are single storey, single or two bay industrial structures. No space divisions (partition walls) are constructed in the longitudinal or transverse direction inside the building. External walls and roof covering define the floor area of the hall, secure the structure against the effects of loads induced by the external environment, and provide required rigidity.

\footnotetext{
${ }^{1}$ Autor do korespondencji / corresponding author: Urszula Pawlak, Politechnika Świętokrzyska, Wydział Budownictwa i Architektury, 25-314 Kielce; al. Tysiąclecia Państwa Polskiego 7. Tel: +48 41 34-24-803, Fax: +48 41 34-43-784, u.pawlak@tu.kielce.pl

2 Michał Szczecina, Politechnika Świętokrzyska, Wydział Budownictwa i Architektury, 25-314 Kielce; al. Tysiąclecia Państwa Polskiego 7. Tel: +48 41 34-24-804, Fax: +48 41 34-43-784, michalsz@tu.kielce.pl
} 
Industrial halls typically accommodate overhead cranes (top running, underhung, or wall travelling cranes), which facilitate handling of heavy loads and ensure smooth transport.

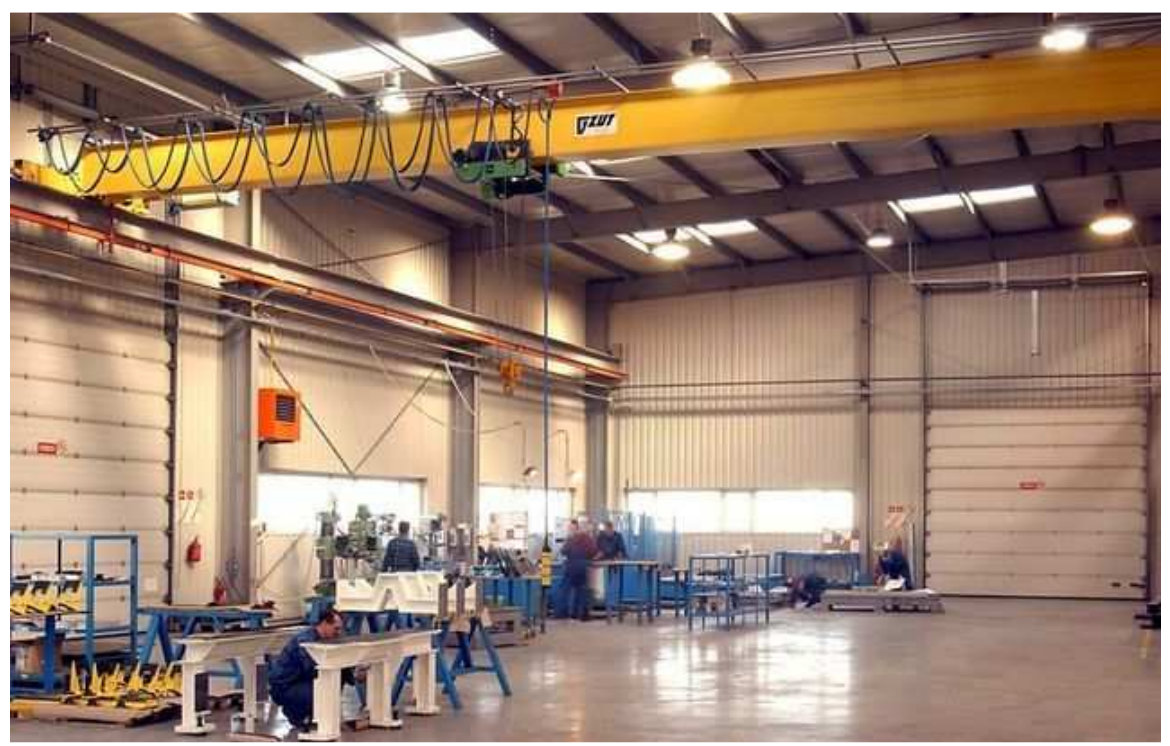

Rys. 1. Przemysłowa hala stalowa z transportem wewnętrznym [2]

Fig. 1. Steel industrial hall with on-site handling [2]

Steel industrial halls carry various dynamic and static loads, such as:

- permanent loads (self weight),

- large roof area-related loads (snow, wind),

- equipment-related loads, e.g., overhead cranes,

- vibration-induced loads and those from handling equipment collisions,

- thermal effects,

- seismic mechanism-related loads.

The design of steel halls takes place in stages and, for the safety of operation and durability of the building, it is preceded by thorough analyses of structural systems, which carry the load to the foundations, in terms of statics, stability and dynamics of the structure.

The paper presents a dynamic evaluation of the stability of a steel industrial hall with on-site handling using the structural stability dynamic criterion proposed by Gomuliński A. and Witkowski M. [3] for dynamic analysis of structural movement stability. 


\section{Dynamic criterion of structural stability evaluation - BASIC concept}

The term dynamic criterion of structural stability evaluation concerns the analysis of harmonic vibrations of the system under large longitudinal forces.

The main structural system is subjected to static, i.e., non-time-varying external load, which induces large axial forces $S$ in the bars. These forces affect the stiffness of structural elements. Compressive forces decrease and tensile forces increase the stiffness of the bars. Further considerations will refer to the case when forces $\mathrm{S}$ induce large compressive forces in the bars.

The stiffness matrix is defined by the following formula (1)

$$
\tilde{K}=K-K_{G}(S)
$$

where

$K$ - linear stiffness matrix,

$K_{G}-$ geometric stiffness matrix.

Determining the conditions under which the system might move about the equilibrium position without the action of external excitation involves the analysis of equation (3). The motion equation (3) results from the equation of energy balance (2)

$$
M \ddot{q}+C \dot{q}+\left(K-K_{G}\right) q=Q(t)
$$

where

$M$ - inertia (mass) matrix,

$\mathrm{C}$ - damping matrix,

$K$ - linear stiffness matrix,

$K_{G}$ - geometric stiffness matrix,

$Q(t)$ - force (time function) forcing the movement,

$q$, $\dot{q}, \ddot{q}$ - vector of displacement, velocity, acceleration,

assuming that $Q(t)=0$ and ignoring damping $C=0$ at the lack of static loads $K_{G}=0$.

$$
M \ddot{q}+\tilde{K} q=0
$$

If we assume that

$$
\ddot{q}=-\omega^{2} \cdot q
$$

formula (3) can be written:

$$
\left(\tilde{K}-\widetilde{\omega}^{2} M\right) q=0
$$


The solution to equation (5) has the form of harmonic functions of variable $\mathrm{t}$ (time), then, if condition (6) is satisfied

$$
\operatorname{det}\left(\tilde{K}-\widetilde{\omega}^{2} M\right)=0
$$

The solution to equation (6) comprises an ordered set of values $\widetilde{\omega}_{i}(\mathrm{i}=1,2, \ldots \mathrm{n})$, i.e., harmonic vibration frequency. The components of matrix $\tilde{K}$ are dependent on the current value of force $S$, which is why it affects values $\widetilde{\omega}_{i}$.

$$
\widetilde{\omega}_{i}=\widetilde{\omega}_{i}(S)
$$

It is impossible to determine the analytic form of (7), but there is a simple way of analysing the effect of force $S$ in the first, the smallest, frequency $\widetilde{\omega}_{1}$. For $\mathrm{S}=0$, matrix $\tilde{K}=K$, therefore equation (6) is equivalent with the equation defining the critical balance state (8), and the values $\widetilde{\omega}_{i}$ express the eigenfrequencies of the structure $\omega_{i}$.

$$
\operatorname{det}\left(K-K_{G}\right)=0
$$

The solution to equation (8) gives the critical values of the load $S_{*}$, which leads to the conclusion that if the force $\mathrm{S}$ reaches the smallest critical value, then solution to (6), i.e., the smallest root, is $\widetilde{\omega}_{1}^{2}=0$.

If we assume that the force $\mathrm{S}$ increases from 0 to the first critical values $S_{*_{1}}$, then the smallest frequency of free harmonic vibrations decreases from $\omega_{1}$ to 0 .

Physical interpretation of this phenomenon is as follows: if force $S$ reaches the critical value, vibration stops. Conversely, if the structure deviated from the equilibrium position does not vibrate and remains in the steady configuration, then the applied $\mathrm{S}$ force takes the critical value.

Expression

$$
\tilde{\omega}_{i}(S)=0
$$

defines the dynamic criterion of the loss of stability [3].

\section{Dynamic criterion of stability loss in steel industrial hall with internal transport - evaluation}

\subsection{A brief description of the structure under investigation}

The steel industrial hall shown in Fig. 2 (cross-section) and Fig. 3 (axonometric projection) was evaluated in terms of dynamic stability. 
The hall is a steel structure constructed on the reinforced concrete footing. It is located in Kielce, in the first wind load zone and third snow load zone. The soil at the foundation level is sandy loam with the index of liquidity $\mathrm{I}_{\mathrm{L}}=0.2$. The foundation level was assumed to be $1 \mathrm{~m}$ below the ground surface level.

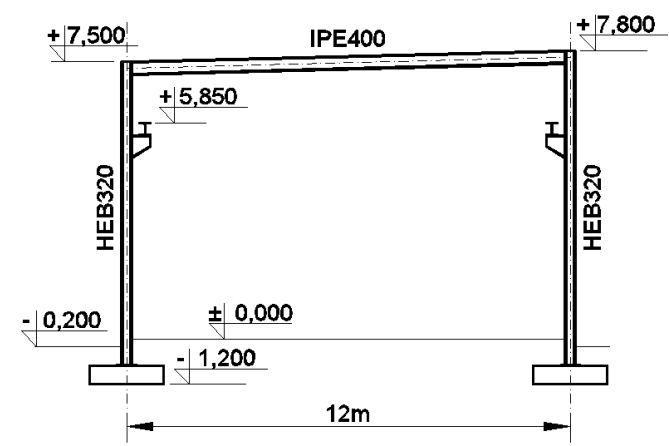

Rys. 2. Przekrój konstrukcji hali przemysłowej z transportem wewnętrznym [4]

Fig. 2. Cross-section of the industrial hall with on-site handling [4]

The main structural system of the hall is a flat steel single bay frame of a single storey building with a monopitch roof and short cantilevers for supporting the runway beam. The connection between the columns and foundations is fully fixed, with a hinged/pinned connection between the steel rafter and the column. The structure has an axial span of $12 \mathrm{~m}$, and its height to the top point of the roof is $7.8 \mathrm{~m}$. The beam of the frame is a solid IPE 400 profile and the column is a solid HEB 320 profile. The running beams lean on a short steel cantilever connected rigidly with the column shank. The steel cantilever was constructed to be a plate element with variable height.

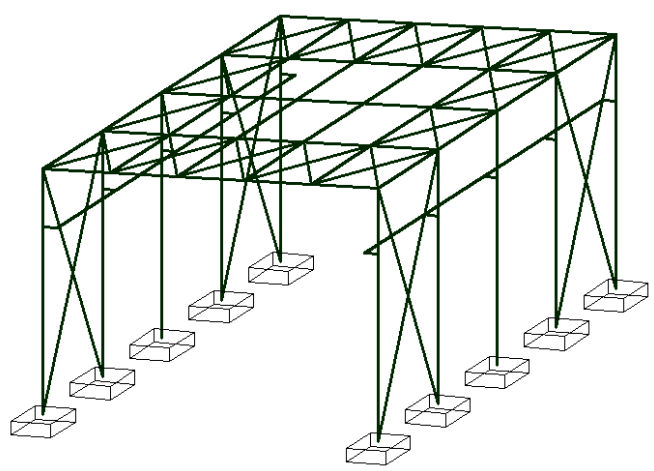

Rys. 3. Rysunek aksonometryczny konstrukcji hali [4]

Fig. 3. Axonometric projection of the hall structure [4] 
The short cantilever is connected with the shank by welding with the use of fillet weld. The joint is additionally strengthened with ribs. The roof beam and the column are connected by bolting.

The spatial layout of the hall comprises five flat structures mentioned above arranged at intervals of $6 \mathrm{~m}$. The roof is made from deep profile roof sheet placed on steel purlins that use IPE 200 sections arranged $2.4 \mathrm{~m}$ apart. Roof bracings were made from steel rods $20 \mathrm{~mm}$ in diameter in the end regions of the roof. All connections in the roof structure were bolted, and the box profile sheet was fastened with self-drilling screws.

Side and end walls were made of sandwich panels mounted to a steel subframe. The bracing in the end regions used an equal leg angle 80x80x6.

The overhead crane girder used a solid profile HEA300. The tracks were secured with buffer stops. The overhead crane ZXJ with a capacity of $50 \mathrm{kN}$ moves at a speed of $40 \mathrm{~m} / \mathrm{min}$. The speed of a trolly is $30 \mathrm{~m} / \mathrm{min}$, and the lifting speed reaches $12.5 \mathrm{~m} / \mathrm{min}$.

The whole structure is made of class S235JR steel, with a pad footing of C30/37 concrete reinforced with RB500W steel.

\subsection{Dynamic criterion of stability of a steel industrial hall with internal transport - analysis}

The evaluation of dynamic stability of the hall used Autodesk Robot Structural Analysis Professional 2014 software, based on the Finite Element Method. The static diagram of the hall is shown in Fig. 4. Nodes from 35 to 38 are the points at which purlins are supported by main girders.

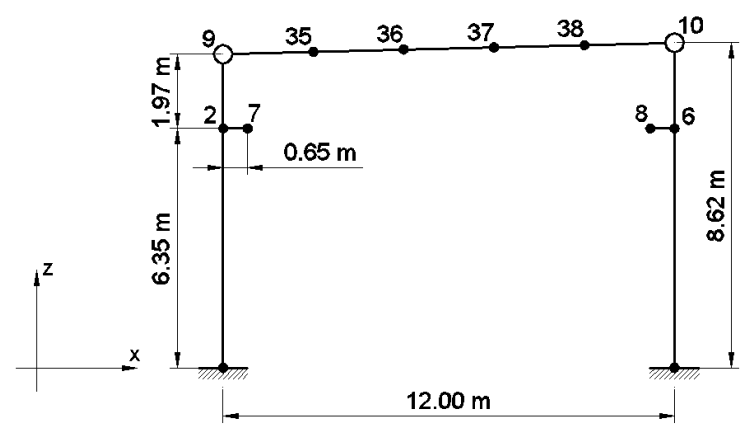

Rys. 4. Schemat statyczny modelu hali [4]

Fig. 4. Static diagram of the hall [4]

The assumption that the axial forces applied to the columns of the structure increase from 0 (no compression; free vibration) to the value equal to the critical force (then some of the natural vibrations should be 0) was the basis for the analysis. The calculations used the FEM for different degrees of discretisation of 
the frame columns to 1, 3 and 5 elements. The results are shown in Fig. 5 in the form of a graph. The graph shows the relationship between the eigenfrequency and axial forces in the columns. Since the degree of discretisation had a negligible effect on the value of the first critical force and the first eigenfrequency, the authors of this paper decided to only present the results for splitting the columns into five finite elements.

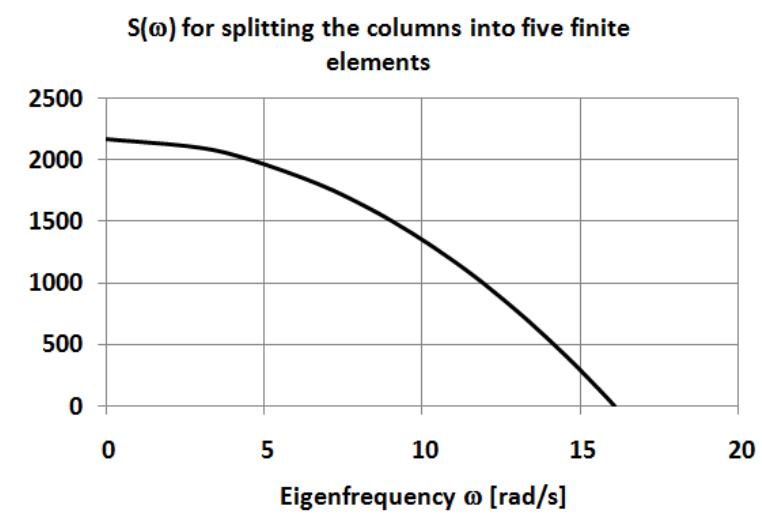

Rys. 5. Zależność $S(\omega)$ dla podziału słupów na 5 elementów skończonych

Fig. 5. Dependence of $S(\omega)$ for splitting the columns into five finite elements

As shown in the graph above, the relationship of the vibration frequency and axial force is non-linear. When the compressive force in the columns approaches the critical value, vibration decays. When the structure is displaced from the equilibrium position and there is no vibration, then the axial force value is equal to that of the critical force. The area closed between the graph and the axes of the coordinate system is called a safety region. If the eigenfrequency and the axial force in the columns form a pair of coordinates of the point contained within the safety region, the structure is not threatened with dynamic stability loss.

\subsection{Deformed geometries of the structure}

Similarly to the case of stability analysis and eigenproblem analysis in dynamics, deformed geometries of structures can be represented as an issue of dynamic stability loss. This paper deals with three such modes:

- in the absence of axial forces, this mode will be the mode of natural vibration (free vibrations),

- if the axial forces are equal to the critical force, buckling occurs and vibrations decay,

- the deformed mode for the axial forces of $1000 \mathrm{kN}$, then the eigenfrequency is $11.91 \mathrm{rad} / \mathrm{s}$. 


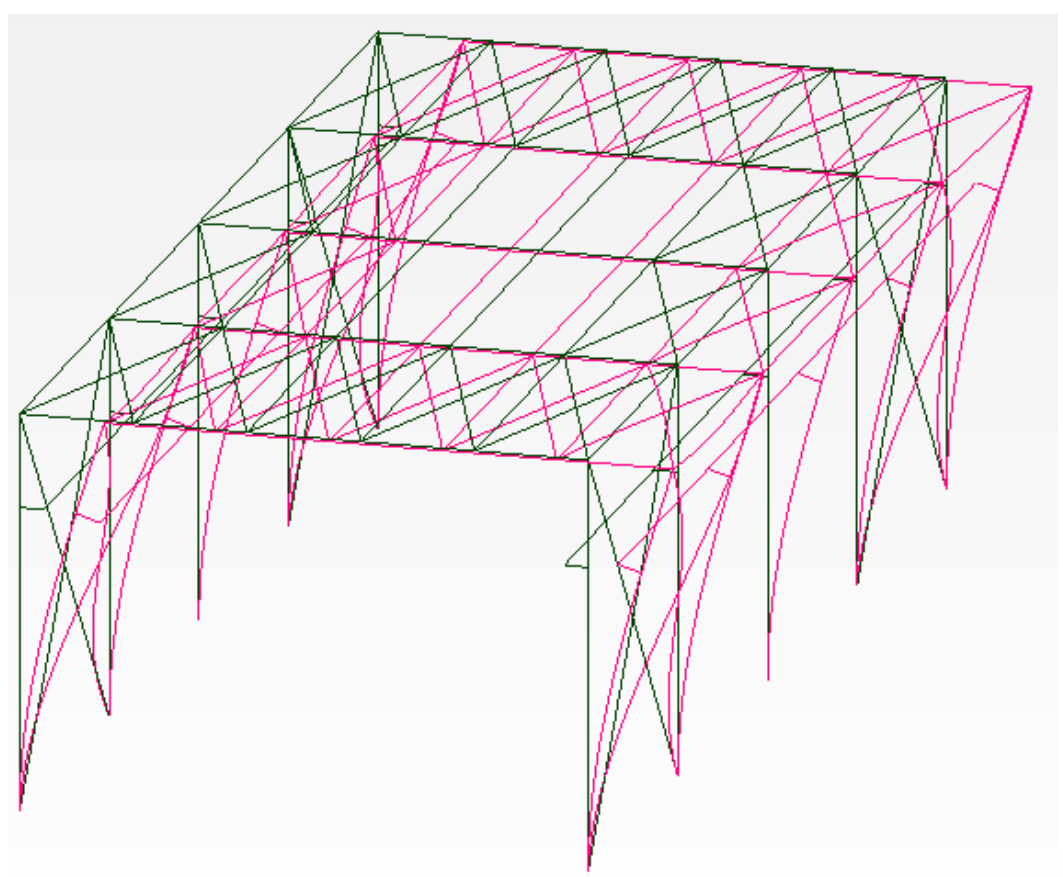

Rys. 6. Postać odkształcona konstrukcji [5]

Fig. 6. Deformed shape of the structure [5]

Figure 6 shows the deformed mode identical for the three cases above. Tables 1,2 and 3 present eigenvectors. For the presented mode, the nodal displacement values correspond to components of eigenvector. The numbers of nodes and the axes are as in Fig. 4.

Tabela 1. Wektor własny przy braku sił osiowych (drgania swobodne)

Table 1. Eigenvector for the absence of axial forces (free vibrations)

\begin{tabular}{|c|c|c|c|c|c|}
\hline Node & Case & Form & Component UX & Component UZ & Component RY \\
\hline 2 & 4 & 1 & 0,00606656 & $-0,00000020$ & 0,00149914 \\
\hline 6 & 4 & 1 & 0,00573902 & 0,00000025 & 0,00142820 \\
\hline 7 & 4 & 1 & 0,00606679 & $-0,00075005$ & 0,00150024 \\
\hline 8 & 4 & 1 & 0,00573924 & 0,00071462 & 0,00142924 \\
\hline 9 & 4 & 1 & 0,00914418 & $-0,00000024$ & 0,00155442 \\
\hline 10 & 4 & 1 & 0,00913328 & 0,00000032 & 0,00149501 \\
\hline 35 & 4 & 1 & 0,00883825 & $-0,00002753$ & 0,00000802 \\
\hline 36 & 4 & 1 & 0,00883854 & $-0,00003892$ & 0,00000198 \\
\hline 37 & 4 & 1 & 0,00883766 & $-0,00003659$ & $-0,00000312$ \\
\hline 38 & 4 & 1 & 0,00883608 & $-0,00002497$ & $-0,00000548$ \\
\hline
\end{tabular}


Tabela 2. Wektor własny dla $\mathrm{S}=2167 \mathrm{kN}$

Table 2. Displacements for $\mathrm{S}=2167 \mathrm{kN}$

\begin{tabular}{|c|c|c|c|c|c|}
\hline Node & Case & Form & Component UX & Component UZ & Component RY \\
\hline 2 & 4 & 1 & 0,00600761 & $-0,00000037$ & 0,00161342 \\
\hline 6 & 4 & 1 & 0,00563370 & 0,00000035 & 0,00153495 \\
\hline 7 & 4 & 1 & 0,00600761 & $-0,00080708$ & 0,00161342 \\
\hline 8 & 4 & 1 & 0,00563370 & 0,00076783 & 0,00153495 \\
\hline 9 & 4 & 1 & 0,00938550 & $-0,00000049$ & 0,00172609 \\
\hline 10 & 4 & 1 & 0,00937549 & 0,00000048 & 0,00167261 \\
\hline 35 & 4 & 1 & 0,00904149 & $-0,00001211$ & 0,00000137 \\
\hline 36 & 4 & 1 & 0,00904101 & $-0,00001135$ & $-0,00000156$ \\
\hline 37 & 4 & 1 & 0,00904101 & $-0,00000692$ & $-0,00000167$ \\
\hline 38 & 4 & 1 & 0,00904168 & $-0,00000564$ & 0,00000106 \\
\hline
\end{tabular}

Tabela 3. Wektor własny dla $\mathrm{S}=1000 \mathrm{kN}$

Table 3. Displacements for $\mathrm{S}=1000 \mathrm{kN}$

\begin{tabular}{|c|c|c|c|c|c|}
\hline Node & Case & Form & Component UX & Component UZ & Component RY \\
\hline 2 & 4 & 1 & 0,00604415 & $-0,00000028$ & 0,00154838 \\
\hline 6 & 4 & 1 & 0,00569713 & 0,00000030 & 0,00147412 \\
\hline 7 & 4 & 1 & 0,00604428 & $-0,00077462$ & 0,00154898 \\
\hline 8 & 4 & 1 & 0,00569725 & 0,00073751 & 0,00147469 \\
\hline 9 & 4 & 1 & 0,00925073 & $-0,00000036$ & 0,00162811 \\
\hline 10 & 4 & 1 & 0,00924014 & 0,00000039 & 0,00157095 \\
\hline 35 & 4 & 1 & 0,00892829 & $-0,00002012$ & 0,00000486 \\
\hline 36 & 4 & 1 & 0,00892829 & $-0,00002576$ & 0,00000033 \\
\hline 37 & 4 & 1 & 0,00892783 & $-0,00002250$ & $-0,00000240$ \\
\hline 38 & 4 & 1 & 0,00892728 & $-0,00001581$ & $-0,00000238$ \\
\hline
\end{tabular}

The analysis indicates that the deformed shape remains unchanged with the axial force increasing in the columns. In the case of a hall with overhead rail, this mode has a sway-like character.

\section{Conclusions}

The performed analysis has a great practical importance, as the designer of steel halls has to account for both compressive forces in the columns and loadinduced vibration. Investigation of $S(\omega)$ is necessary for all buildings of this type and provides the answer to the fundamental question concerning the dynamic criterion of stability. A close relationship between axial forces and eigenfrequency of the structure is the reason why these quantities cannot be considered separately. 


\section{References}

[1] Przewodnik projektanta, Konstrukcje stalowe w Europie, Nowoczesne Hale, Wydawnictwo Elamem, 2013.

[2] gzut.pl (dostęp: 13.02.2017 r.).

[3] Gomuliński A., Witkowski M., Mechanika budowli, kurs dla zaawansowanych, OWPW, Warszawa 1993.

[4] Szczecina M., Projekt hali z transportem wewnętrznym w Kielcach.

[5] Autodesk Robot Structural Analysis Professional 2014 - user's guide.

\section{DYNAMICZNE KRYTERIUM OCENY STATECZNOŚCI STALOWEJ HALI PRZEMYSLOWEJ Z TRANSPORTEM WEWNĘTRZNYM}

\section{Streszczenie}

W referacie przedstawiono zagadnienie dynamicznej utraty stateczności hali stalowej $\mathrm{z}$ transportem wewnętrznym. Analizę przeprowadzono metodą elementów skończonych. Jako wynik obliczeń przedstawiono zależność częstości drgań własnych konstrukcji od siły ściskającej w słupach konstrukcji. Na podstawie wyników analizy sformułowano podstawowe zalecenia dla projektantów konstrukcji hal stalowych z transportem wewnętrznym.

Słowa kluczowe: hale stalowe, transport wewnętrzny, stateczność, dynamika

Przestano do redakcji: 14.02 .2017 r

Przyjęto do druku: 28.04.2017 r. 